\title{
Determination of lipid oxidation products in vegetable oils and marine omega-3 supplements
}

\author{
Bente Lise Halvorsen and Rune Blomhoff* \\ Department of Nutrition, Institute of Basic Medical Sciences, University of Oslo, Oslo, Norway
}

\section{Abstract}

Background: There is convincing evidence that replacing dietary saturated fats with polyunsaturated fats (PUFA) decreases risk of cardiovascular diseases. Therefore, PUFA rich foods such as vegetable oils, fatty fish, and marine omega-3 supplements are recommended. However, PUFA are easily oxidizable and there is concern about possible negative health effects from intake of oxidized lipids. Little is known about the degree of lipid oxidation in such products.

Objective: To assess the content of lipid oxidation products in a large selection of vegetable oils and marine omega-3 supplements available in Norway. Both fresh and heated vegetable oils were studied.

Design: A large selection of commercially available vegetable oils and marine omega-3 supplements was purchased from grocery stores, pharmacies, and health food stores in Norway. The content of lipid oxidation products were measured as peroxide value and alkenal concentration. Twelve different vegetable oils were heated for a temperature $\left(225^{\circ} \mathrm{C}\right)$ and time $(25$ minutes $)$ resembling conditions typically used during cooking. Results: The peroxide values were in the range $1.04-10.38 \mathrm{meq} / \mathrm{kg}$ for omega-3 supplements and in the range $0.60-5.33 \mathrm{meq} / \mathrm{kg}$ for fresh vegetable oils. The concentration range of alkenals was $158.23-932.19 \mathrm{nmol} / \mathrm{mL}$ for omega-3 supplements and 33.24-119.04 nmol/mL for vegetable oils. After heating, a 2.9-11.2 fold increase in alkenal concentration was observed for vegetable oils.

Conclusions: The contents of hydroperoxides and alkenals in omega-3 supplements are higher than in vegetable oils. After heating vegetable oils, a large increase in alkenal concentration was observed.

Keywords: lipid oxidation; commercially available; vegetable oils; marine omega-3 supplements; screening; peroxide value; alkenal concentration

Received: II November 2010; Revised: 26 April 20II; Accepted: 7 May 20I I; Published: 10 June 20I I

$\mathrm{O}$ ur diet contains a complex mixture of fats and oils consisting of different fatty acids which may affect human health. A joint Food and Agriculture Organization of the United Nations/World Health Organization (FAO/WHO) report from 2009 claims that there is convincing evidence that replacing dietary saturated fatty acids (SF) with polyunsaturated fatty acids (PUFA) decreases the risk of cardiovascular diseases (CVD) (1). The report recommends replacing SF in the diet with PUFA. In practice, this may be done by replacing foods such as high fat dairy products and fatty meat, with foods such as several vegetable oils (not palm oil and coconut oil), fatty fish and fish oils.

Several epidemiologic and clinical studies have shown that intake of fish or fish oil decreases mortality and morbidity, as well as risk factors of $\operatorname{CVD}(2,3)$. These effects have mainly been assigned to the long chain omega-3 fatty acids docosahexaenoic acid (DHA) and eicosapentaenoic acid (EPA). Even though PUFA show protective effects against CVD, there is concern about possible negative health effects from ingestion of oxidized lipids from fish oils $(4,5)$. Also for vegetable oils there is concern about the large amounts of oxidation products that are formed during different cooking processes of culinary oils $(5,6)$. Some animal experiments indicate that intake of oxidized lipids from vegetable oils might be harmful for humans (7-9). Additionally, some studies do not show protective effects on CVD after intake of fish oil $(10,11)$. Whether these aberrant effects are results of intake of oxidized omega-3 products, too high or too low doses or other factors are unknown. In most studies the oxidative status of the fish oil is not determined. 
It is well known that lipids in edible oils are susceptible to auto-oxidation and photo-oxidation during processing and storage (12). This has long been recognized as a major problem for the oil industry, leading to undesirable flavours and taste, decomposing the nutritional quality, and leading to production of toxic compounds. The oxidation of oils is influenced by many factors such as the fatty acid composition (i.e. the degree of unsaturation), oil processing, heat, light, transition metals and antioxidants.

Several lipid oxidation products may be absorbed and metabolised in humans (4). The primary lipid oxidation products, lipid hydroperoxides, may decompose into secondary oxidation products such as the highly reactive and cytotoxic 4-hydroxy-2-alkenals (12). In a recent study by Pillon el al. (13), such compounds were toxic to L6 muscle cells and had a dramatic effect on cell viability even at low concentrations. In a different study, the daily exposure to 4-hydroxy-2-alkenals in Korean foods was estimated (14). It was concluded that the Korean intake of dietary 4-hydroxy-2-alkenals may not constitute a risk for human health. The lack of a safe dose for such compounds and the uncertainty of the bioavailability of protein bound 4-hydroxy-2-alkenals were also considered.

Several methods have been used to measure a variety of oxidation products (15-21). Lipid hydroperoxide is one commonly measured parameter. Traditionally, iodometric titration has been the preferred method for measurement of hydroperoxides as peroxide value (PV). Common measures of secondary lipid oxidation products are, for example, the anisidine value and malondialdehyde (MDA). However, commercial kits are also available for measurements of PV and secondary oxidation products (MDA, alkenals) (19, 22, 23).

In several smaller scale studies, the oxidative status of a few products has been presented $(4,24-27)$. These studies indicate that the oxidative status between different products varies. Therefore, in order to examine the level of lipid oxidation products in commonly consumed vegetable oils and marine oils, a large selection of products were purchased from local grocery stores, health food stores, and pharmacies in Norway, and the content of primary and secondary oxidation products were measured. Because heat is an important factor that accelerates the oxidation processes of oils, several vegetable oils were heated for a period and at a temperature typically used during food preparation. The temperature chosen were in the higher level of what is typical for roasting in oven. The content of primary and secondary oxidation products were measured in both fresh and heated samples. The results from the present study are useful when planning experimental studies or intervention trials elucidating the potential harmful effect of oxidized fish- and vegetable oils.

\section{Materials and methods}

\section{Sample collection}

Samples were purchased from grocery stores, health food shops, and pharmacies in Norway. All stores were located in Oslo and Akershus, two densely populated counties in Norway. Only large and well known stores were chosen. It was attempted to purchase at least three different products of the same type of vegetable oil (e.g. at least three different product of extra virgin olive oils, three different products of olive oils, three different products of soybean oil etc.). For both vegetable oils and marine omega-3 supplements it was attempted to collect products from different brands/ manufacturers. Four omega-3 supplements were ordered from the internet (OmegaPro, Lofotkapselen, Fri Flyt Omega-3 and Salmon oil from Norwegian Fish oil). Generally, at least three samples per product were purchased, preferably from different shops, for quantitation of peroxide value (PV) and alkenal content. Only one sample was purchased for each of the four omega-3 products ordered from the internet. For some products, one sample was purchased for quantitation of PV only. All samples were stored as recommended on the packaging. With the exception of the vegetable oils that should be heated (see below), all samples were sealed until analysis. Information about products in this study is included in Tables 2 and 3. A more detailed description of all marine omega-3 products used in this study is attached as 'Table $\mathrm{S} 1$ and $\mathrm{S} 2$ ' to this article.

\section{Heating of vegetable oil samples}

Twenty-five millilitre vegetable oil was transferred to a $600 \mathrm{~mL}$ beaker and heated for 25 minutes at $225^{\circ} \mathrm{C}$ in an oven. Samples were cooled, transferred to a $100 \mathrm{~mL}$ bottle and placed, together with corresponding fresh sample, in a dark cooling room $\left(4^{\circ} \mathrm{C}\right)$ until analysis on the following day. Three samples were purchased, heated and analysed for each of the 12 vegetable oil products tested.

\section{Kits}

PeroxySafe $^{\mathrm{TM}}$ kit-STD assay, AlkalSafe ${ }^{\mathrm{TM}}$ kit-STD assay, and STD controls were purchased from SafTest, Inc (a division of MP Biomedicals, OH, USA).

\section{Measurement of peroxide value (PV) using the PeroxySafe ${ }^{T M}$ Kit-STD assay}

The PeroxySafe ${ }^{\mathrm{TM}}$ STD kit was performed according to the procedure following the kit. However, some modifications were made. Briefly, all volumes were halved compared to the original sample preparation procedure and a Beckman DU ${ }^{\circledR} 640$ spectrophotometer (Beckman Instruments, Inc. (now Beckman Coultier, Inc.), CA, USA) was used for the measurements of absorbance at $570 \mathrm{~nm}$. All samples were measured in duplicates. Samples with PV above $5.0 \mathrm{meq} / \mathrm{kg}$ were diluted to ensure 
the concentration to be within the concentration rage of the calibration curve.

The within-day repeatability measured as relative standard deviations (RSD \%) were 5.6\%, 4.0\%, and $3.9 \%$ for the low, medium and high control, respectively. The between-day repeatability measured as $\mathrm{RSD} \%$ were $8.1 \%, 4.9 \%$ and $3.4 \%$ for the low, medium and high control, respectively.

Measurement of alkenals using the AlkalSafe ${ }^{T M}$ Kit-STD assay The AlkalSafe ${ }^{\mathrm{TM}}$ STD kit was performed according to the procedure following the kit. However, some modifications were made. All volumes were halved compared to the original sample preparation procedure and a Beckman $\mathrm{DU}^{\circledR} 640$ spectrophotometer was used for the measurements of absorbance at $550 \mathrm{~nm}$. All samples were measured in duplicates. Samples with alkenal concentration above $64.0 \mathrm{nmol} / \mathrm{mL}$ were diluted and reanalysed. If the alkenal concentration was below 8.0 $\mathrm{nmol} / \mathrm{mL}$, a six times dilution was made and the sample was reanalysed.

The within-day repeatability measured as $\mathrm{RSD} \%$ was $3.1 \%$. The between-day repeatability measured as $\mathrm{RSD} \%$ was $2.4 \%$. The control sample was used for testing of both within- and between-day repeatability.

\section{Statistics}

Pearson correlation coefficients were calculated for the relationship between PV and alkenal concentration for omega-3 products and vegetable oils, respectively, and for the relation between the number of days until expiry and PV and alkenal concentration for both products. The statistical program PASW (Predictive Analytics SoftWare) Statistics 18 (SPSS Inc., Chicago, IL, USA) was employed.

\section{Results}

The results presented in Table 1 show that there are large variations in lipid oxidation of the marine omega- 3 supplements and vegetable oils tested, both regarding formation of primary and secondary oxidation products. The results also show that omega-3 supplements contain more lipid oxidation products compared to vegetable oils; the alkenal value of the most oxidized vegetable oil was lower than the omega-3 supplement with lowest alkenal value.
The content of primary oxidation products measured as PV of the omega-3 supplements were in the range 1.04 $10.83 \mathrm{meq} / \mathrm{kg}$. This corresponds to a 10.4 -fold difference between the lowest and highest value. The mean value was $3.61 \mathrm{meq} / \mathrm{kg}$. The secondary oxidation products measured as alkenal concentration of omega-3 supplements were in the range $158.23-932.19 \mathrm{nmol} / \mathrm{mL}$. This corresponds to almost a six-fold difference between the highest and lowest value. The mean concentration was $492.43 \mathrm{nmol} / \mathrm{mL}$. These results imply that less than $0.16 \%(\mathrm{w} / \mathrm{w})$ of the total fatty acids in the original omega-3 supplements was detected as peroxidized fatty acids (with the assumption that each fatty acid only has the possibility to be peroxidized once) and that less than $0.0093 \%$ was detected as alkenals in the oil. The individual PV and alkenal concentration of all omega-3 supplements tested are presented in Table 2. No significant correlation $(\mathrm{r}=$ 0.353, $p=0.098$ ) between PV and alkenal concentration was found for omega-3 supplements.

Table 1 also shows that PV of the vegetable oils tested were in the range $0.60-5.33 \mathrm{meq} / \mathrm{kg}$. This corresponds to almost a 9-fold difference between the lowest and highest value. The mean value was $2.43 \mathrm{meq} / \mathrm{kg}$. The alkenal concentrations of vegetable oils were in the range 33.24 $119.04 \mathrm{nmol} / \mathrm{mL}$. This corresponds to a 3.6-fold difference between the highest and lowest value. The mean concentration was $68.93 \mathrm{nmol} / \mathrm{mL}$. These results imply that less than $0.073 \%(\mathrm{w} / \mathrm{w})$ of the total fatty acids in the vegetable oils was peroxidized (with the assumption that each fatty acid only has the possibility to be peroxidized once) and that less than $0.0012 \%$ was detected as alkenals in the oil. The individual PV and alkenal concentration of all vegetable oil products tested are presented in Table 3. A significant correlation $(\mathrm{r}=0.823, p<0.001)$ between the $\mathrm{PV}$ and alkenal concentration was found for vegetable oils.

As can be seen from Fig. 1, heating vegetable oils increased PV in nine products and decreased PV in three products. The change of PV of heated oils was in the range $0.7-5.8$ times compared to fresh oils. The formation of secondary lipid oxidation products, alkenals, increased in all vegetable oils that were heated. The increase in alkenal concentration of heated oils was in the range 2.911.2 times compared to the corresponding fresh oil. The maximum PV observed for heated oil was $4.6 \mathrm{meq} / \mathrm{kg}$ and maximum alkenal concentration was $538.2 \mathrm{nmol} / \mathrm{mL}$. This corresponds to about $0.064 \%$ (w/w) peroxidized

Table 1. Descriptive of the two groups of samples, marine omega-3 supplements and vegetable oils, tested

\begin{tabular}{|c|c|c|c|c|c|}
\hline Sample & Oxidation product & Min & Max & Mean & Median \\
\hline Omega-3s & $\mathrm{PV}(\mathrm{meq} / \mathrm{kg})$ & 1.04 & 10.83 & 3.61 & 3.19 \\
\hline Vegetable oils & $\mathrm{PV}(\mathrm{meq} / \mathrm{kg})$ & 0.60 & 5.33 & 2.43 & 2.25 \\
\hline Omega-3s & Alkenal (nmol/mL) & I58.23 & 932.19 & 492.43 & 393.89 \\
\hline Vegetable oils & Alkenal (nmol/mL) & 33.24 & 119.04 & 68.93 & 68.37 \\
\hline
\end{tabular}


Table 2. Peroxide value (PV) $(\mathrm{meq} / \mathrm{kg})$ and alkenal concentration $(\mathrm{nmol} / \mathrm{mL})$ of different marine omega-3 supplements

\begin{tabular}{|c|c|c|c|c|c|}
\hline Product & $\mathrm{PV}(\mathrm{meq} / \mathrm{kg})$ & $\mathrm{SD}^{\mathrm{a}}(\mathrm{meq} / \mathrm{kg})$ & $n^{b}$ & Alkenal (nmol/mL) & $\mathrm{SD}^{\mathrm{a}}(\mathrm{nmol} / \mathrm{mL})$ \\
\hline $\begin{array}{l}\text { Daily Wellness Biomega fish oil, highly concentrated, } 60 \% \text { Omega-3 } \\
1000 \mathrm{mg}\end{array}$ & 4.08 & 0.47 & 5 & 396.18 & 26.53 \\
\hline Eskimo-3 kids, with Tutti- Frutti taste & 1.44 & 0.57 & 4 & 331.63 & 11.74 \\
\hline Krill-Omega & 7.24 & 0.37 & 4 & 883.62 & 25.97 \\
\hline Möller's cod liver oil, natural & 1.04 & 0.27 & 4 & 206.60 & 26.94 \\
\hline Möller's Extra Omega-3 cod liver oil & 1.13 & 0.49 & 4 & 383.39 & 46.75 \\
\hline Möller's Omega-3 highly concentrated, with peppermint taste & 2.29 & 0.28 & 4 & 371.50 & 27.26 \\
\hline Natural Omega-3 (from Biopharma) & 5.33 & 3.20 & 4 & 470.56 & 77.27 \\
\hline Oil4Life Cardio & 4.52 & 1.17 & 4 & 329.52 & 28.40 \\
\hline Pikasol Hele deg, highly concentrated Omega-3, 880 mg & 2.64 & 0.18 & 4 & 562.54 & 124.09 \\
\hline Ruis Omega-3 Seal oil, capsules & 2.19 & 0.62 & 4 & 359.79 & 45.97 \\
\hline Ruis Omega-3 Seal oil, liquid & 2.93 & 0.28 & 4 & 379.30 & 32.78 \\
\hline Seal oil (from Biopharma) & 4.68 & 2.15 & 4 & 393.89 & 172.50 \\
\hline Triomega Original, highly concentrated & 4.67 & 2.10 & 4 & 932.19 & 359.87 \\
\hline Triple Omega-3, extra strong (from Biopharma) & 3.44 & 1.03 & 4 & 761.47 & 70.51 \\
\hline Lofot cod liver oil & 2.58 & 0.17 & 3 & 295.61 & 10.81 \\
\hline Möller's double & 2.67 & 0.33 & 3 & 571.69 & 65.93 \\
\hline Nycoplus Apotekets cod liver oil, lemon taste & 1.99 & 0.29 & 3 & 880.06 & 39.01 \\
\hline Nycoplus Omega-3, 1000 mg & 2.66 & 1.18 & 3 & 610.12 & 51.13 \\
\hline Nycoplus Seal oil, 1000 mg & 2.34 & 0.05 & 3 & 337.10 & 9.03 \\
\hline Daily Wellness Seal oil Omega-3, DPA, EPA, DHA 500 mg & 4.24 & & I & & \\
\hline Eskimo-3 with Pufanox & 3.07 & & 1 & & \\
\hline Extra strong Omega-3, with krill antioxidant (from Biopharma) & 3.51 & & 1 & & \\
\hline Fri Flyt Omega-3 & 6.56 & & I & 315.73 & \\
\hline Lofotkapselen, pure highly concentrated Omega-3 & 4.95 & & 1 & 911.08 & \\
\hline Norwegian Fish oil, Salmon oil & 3.19 & & 1 & 158.23 & \\
\hline OliVita oil, Seal oil and Olive oil & 3.95 & & 1 & & \\
\hline OmegaPro & 2.01 & & 1 & 484.14 & \\
\hline PreviShop Omega-3 Forte, highly concentrated fish oil & 2.81 & & 1 & & \\
\hline Pure Arctic Omega-3 & 10.83 & & 1 & & \\
\hline $\begin{array}{l}\text { Ruis OliMar Pluss, Omega-3 Seal oil with olive leaf extract, } \\
\text { grape seed oil and vitamin K2 }\end{array}$ & 3.30 & & 1 & & \\
\hline Ruis Omega-3 Seal oil, highly concentrated & 3.99 & & 1 & & \\
\hline Suncap Omega-3 & 3.59 & & I & & \\
\hline Triomega, Omega-3+Q10, heart & 3.19 & & 1 & & \\
\hline
\end{tabular}

${ }^{a} \mathrm{SD}=$ standard deviation.

${ }^{b} n=$ number of replicates.

fatty acids and about $0.0054 \%$ alkenals in the oil. The four products with lowest alkenal content after heating were all olive oils, two of which were extra virgin olive oils and two were olive oils. Sunflower oils and soybean oils, along with one corn oil, had the highest alkenal content after heating.

A significant negative correlation $(\mathrm{r}=-0.557, p<$ 0.001 ) was found between the number of days until expiry and the PV of marine omega- 3 supplements (Fig. 2A). No such correlation was found for the PV of vegetable oils or the alkenal concentration of either omega-3 products or vegetable oils (Fig. 2B-D).

\section{Discussion}

In this paper we present a comprehensive study of the oxidative status of a large selection of commercial vegetable oils and marine omega- 3 supplements available in Norway. There are numerous papers showing beneficial health effects after intake of fish oils and vegetable oils (28-31). However, possible negative health effects of intake of oxidized lipids have also been suggested $(4,5)$. Oxidation of edible oils occurs when MUFA and PUFA, which are mainly glycerol bound, react with atmospheric $\mathrm{O}_{2}$. Primary oxidation products, hydroperoxides, are formed through different chemical 
Table 3. Peroxide value (PV) (meq/kg) and alkenal concentration $(\mathrm{nmol} / \mathrm{mL})$ of different fresh vegetable oils

\begin{tabular}{|c|c|c|c|c|c|c|}
\hline Produkt & $\mathrm{PV}(\mathrm{meq} / \mathrm{kg})$ & $\mathrm{SD}(\mathrm{meq} / \mathrm{kg})^{a}$ & $\mathrm{n}^{b}$ & Alkenal (nmol/mL) & $\mathrm{SD}(\mathrm{nmol} / \mathrm{mL})^{a}$ & $\mathrm{n}^{b}$ \\
\hline Clearspring unrefined organic italian extra virgin olive oil & 5.33 & 1.05 & 4 & 119.04 & 27.22 & 3 \\
\hline Clearspring unrefined organic sunflower oil & 4.70 & 0.10 & 3 & 71.28 & 1.83 & 3 \\
\hline Coop Corn oil & 0.83 & 0.31 & 4 & $33.24^{c}$ & 9.90 & 3 \\
\hline Coop Nature Ecological Olive oil, Extra Virgin cold pressed & 4.19 & 1.02 & 3 & 96.15 & 33.09 & 3 \\
\hline Coop Olive oil (glass bottle) & 2.27 & 0.28 & 4 & 61.77 & 2.81 & 3 \\
\hline Coop Soy bean oil & 1.64 & 0.28 & 4 & 64.65 & 1.38 & 3 \\
\hline Eldorado Corn oil & 1.52 & 0.04 & 3 & $44.32^{c}$ & 2.64 & 3 \\
\hline Eldorado Sunflower oil & 1.96 & 0.16 & 3 & 84.61 & 8.02 & 3 \\
\hline Figaro extra virgin olive oil, Premium quality & 3.53 & 0.43 & 3 & 61.31 & 10.45 & 3 \\
\hline Fígaro olive oil, Premium quality & 2.11 & 0.03 & 3 & 71.79 & 7.75 & 3 \\
\hline Gaea Ecological Extra Virgin Olive oil & 4.28 & 0.23 & 3 & 98.83 & 10.65 & 3 \\
\hline Gaea Kalamata D.O.P. Extra Virgin Olive oil & 3.80 & 0.54 & 4 & 85.38 & 10.79 & 3 \\
\hline Iliada Kalamata Extra Virgin Olive oil (glass marasqua bottle) & 3.72 & 0.36 & 3 & 88.11 & 9.66 & 3 \\
\hline Mills Soy bean oil & 0.60 & 0.09 & 4 & 54.95 & 3.12 & 3 \\
\hline Monini Extra Virgin Olive oil, Classico & 3.78 & 0.44 & 4 & 86.14 & 4.65 & 3 \\
\hline Odelia Norwegian cold-pressed rape-seed oil, for frying & 1.96 & 0.25 & 4 & 53.86 & 9.09 & 3 \\
\hline Unió Siurana extra virgin olive oil & 3.04 & 0.39 & 3 & 65.46 & 6.44 & 3 \\
\hline Vita Hjertego' Optimal & 1.01 & 0.24 & 4 & $36.87^{c}$ & 1.41 & 3 \\
\hline X-tra Olive oil & 2.67 & 0.20 & 4 & 74.01 & 2.71 & 3 \\
\hline Ybarra 'Aromático' Extra Virgin olive oil Selección & 3.10 & 0.50 & 4 & 77.86 & 17.00 & 3 \\
\hline Ybarra Olive oil (glass bottle) & 1.92 & 0.46 & 4 & $42.44^{c}$ & 6.90 & 3 \\
\hline Ybarra Olive oil (plastic bottle) & 2.00 & 0.14 & 3 & $44.44^{c}$ & 2.09 & 3 \\
\hline Amphora Rapeseed oil & 0.74 & & 1 & & & \\
\hline Amphora Sunflower oil & 2.22 & & I & & & \\
\hline Coop Sunflower oil & 1.28 & & 1 & & & \\
\hline Hojiblanca extra virgin olive oil & 2.71 & & 1 & & & \\
\hline La Española extra virgin olive oil & 2.83 & & 1 & & & \\
\hline La Española extra virgin olive oil, enriched with Omega 3 & 4.08 & & 1 & & & \\
\hline Odelia Norwegian cold-pressed Rape [-seed] oil, for baking & 2.42 & & 1 & & & \\
\hline Oil for deep-frying & 2.29 & & 1 & & & \\
\hline Orkide refined corn oil & 1.72 & & 1 & & & \\
\hline Orkide refined soybean oil & 0.71 & & 1 & & & \\
\hline Orkide refined sunflower oil & 1.40 & & 1 & & & \\
\hline Rape [-seed] oil, cold-pressed (from Askim Frukt- og Bærpresseri) & 2.79 & & 1 & & & \\
\hline R-oil Cotswold farm, cold-pressed Rape [-seed] oil & 1.66 & & 1 & & & \\
\hline First Price Cooking oil (contains refined rape [-seed] oil) & 0.63 & & 1 & & & \\
\hline
\end{tabular}

${ }^{a} \mathrm{SD}=$ standard deviation.

${ }^{b} n=$ number of replicates.

${ }^{c}$ Result below LOQ.

mechanisms (12). The hydroperoxides will further break down into secondary oxidation products (aldehydes, ketones, alkenals etc). Several of them possess toxic properties. Eventually, tertiary oxidation products (short chain free fatty acids) may be formed. These oxidation reactions may be accelerated by the presence of metals and by exposure to heat and light.

The fish oil supplements tested contained different levels of hydroperoxides and alkenals. These differences could be due to several factors such as processing of the fish and production of fish oil, storage, the antioxidants added, and the presence of metals and light (4). Generally, a fat is rancid when the PV is about $10 \mathrm{meq} /$ $\mathrm{kg}$ and a fresh and refined product should have PV below $1 \mathrm{meq} / \mathrm{kg}$ (32). However, more specifically for fish oils, different upper limits of PV have been suggested. For instance, a maximum level of $2 \mathrm{meq} / \mathrm{kg}$ is suggested by Turner et al. (4) while $8 \mathrm{meq} / \mathrm{mL}$ is suggested by Boran et al. (33) and $10 \mathrm{meq} / \mathrm{kg}$ is described by Kolanowski (27). Compared to a recommended upper limit of PV of 8 or 10 

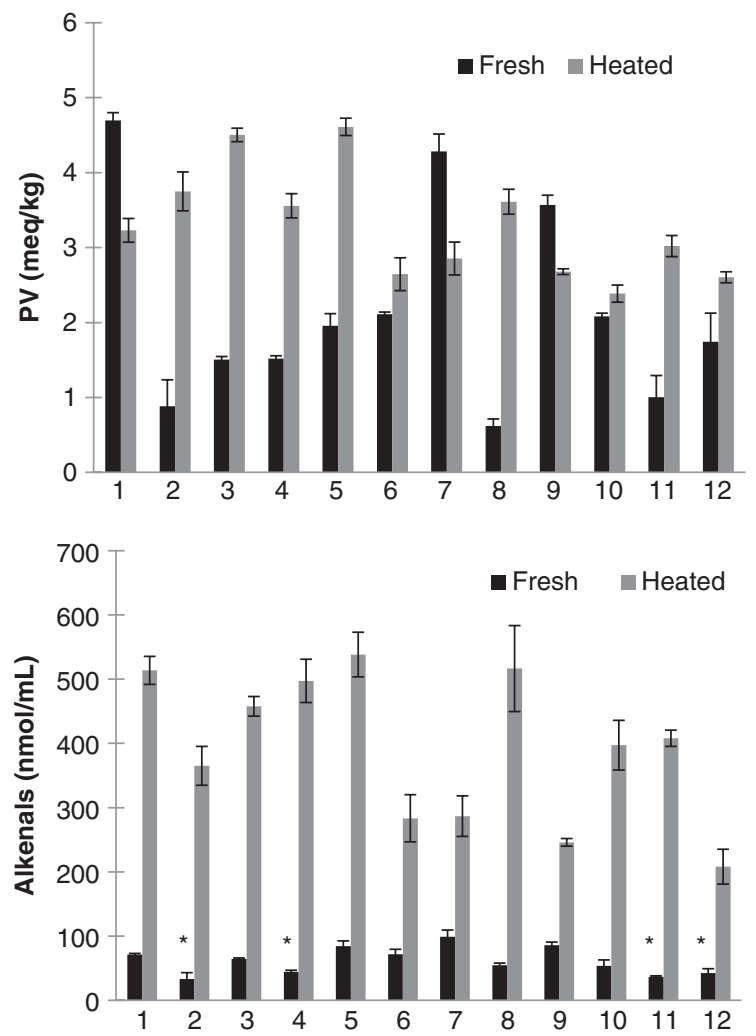

Fig. 1. Peroxide values (PV) (meq/kg) and alkenal concentrations $(\mathrm{nmol} / \mathrm{mL})$ before and after heating of $25 \mathrm{~mL}$ vegetable oil at $225^{\circ} \mathrm{C}$ for 25 minutes. The following products were tested: 1: Clearspring unrefined organic sunflower oil; 2: Coop Corn oil; 3: Coop Soy bean oil; 4: Eldorado Corn oil; 5: Eldorado Sunflower oil; 6: Fígaro olive oil, Premium quality; 7: Gaea Ecological Extra Virgin Olive oil; 8: Mills Soy bean oil; 9: Monini Extra Virgin Olive oil, Classico; 10: Odelia Norwegian cold-pressed rape-seed oil, for frying; 11: Vita Hjertego' Optimal; 12: Ybarra Olive oil (glass bottle). *Result below LOQ.

meq $/ \mathrm{kg}$, only a few products included in the present study reached this upper limit. If, however, the lowest maximum limit of $2 \mathrm{meq} / \mathrm{kg}$ is accepted, most products exceed the upper limit. Also, because many secondary oxidation products may possess toxic properties, the variation in content of alkenals is interesting $(5,34)$. A recent study of 19 fish oil supplements available in Poland showed PV in the range 1.0-9.8 meq/ $/ \mathrm{kg}$, which is comparable to the results in the present study of products available in Norway (27). Turner et al. (4) analyzed six different anonymised commercial fish oil supplements. They found $\mathrm{PV}$ and anisidine values in the range $3.2-5.5 \mathrm{meq} / \mathrm{kg}$ and $9-20$, respectively. They conclude that most commercially available fish oil supplements contain more hydroperoxides and secondary oxidation products than recommended (upper limit of PV of $2 \mathrm{meq} / \mathrm{kg}$ and $\mathrm{AV}$ of 10).

Fish oils contain high amounts of EPA and DHA, compared to vegetable oils. The high content of these highly unsaturated and easily oxidizable fatty acids may explain the higher content of lipid oxidation products in fish oils compared to vegetable oils found in the present study. This may also explain the observed significant inverse relation between the number of days until expiry date and the PV of omega-3 products which is not observed for vegetable oils.

The vegetable oils examined in the present study, also showed variations in PV and alkenals. However, only one product had a $\mathrm{PV}$ above $5 \mathrm{meq} / \mathrm{kg}$ and an alkenal content above $100 \mathrm{nmol} / \mathrm{mL}$. Of 35 products, 14 had a PV below 2 $\mathrm{meq} / \mathrm{kg}$. These variations can arise from different factors such as the degree of unsaturation of the fatty acids present in the particular oil, storage, exposure to light, and the content of metals or other compounds that may catalyze the oxidation processes (12).

Even though fresh vegetable oils were not oxidized extensively, heating altered the content of lipid oxidation products considerably. The PV increased in most products. However, in 3 out of 12 products the PV were decreased after heating. Hydroperoxides are unstable to heat and will easily decompose to the more stable secondary oxidation products under such conditions. In those three cases, the decomposition of hydroperoxides was probably faster than the formation. Moreover, a considerable increase in the content of the more stable alkenals appeared for all 12 products. The four products with lowest alkenal content after heating were all olive oils. Olive oils contain mainly MUFA (about 76\%). The five products with highest alkenal content after heating were sunflower oil, soybean oil, and one corn oil, containing about $69 \%, 61 \%$, and $62 \%$ PUFA, respectively. These results are consistent with the assumption that MUFA are more resistant to oxidation and heat than PUFA.

The average intake of edible oils and fats in the Norwegian population is about $34 \mathrm{~g} / \mathrm{day}$ (35). Edible oils consists mainly of different types of vegetable oils. Hence, the volume of vegetable oils in the diet is probably about 10-50 times the intake of fish oil supplements. Vegetable oils, particularly cooked vegetable oils, may therefore be a much larger dietary source of both primary and secondary oxidation products than fish oil supplements. By comparison, one dose of $2 \mathrm{~mL}$ omega-3 supplement may equal a $\mathrm{PV}$ and an alkenal content of $0.007 \mathrm{meq}$ and $1 \mu \mathrm{mol}$, respectively; while a dose of $20 \mathrm{~mL}$ heated vegetable oil may equal a PV and alkenal content of 0.07 meq and 7.9 $\mu \mathrm{mol}$, respectively. A large dose of $100 \mathrm{~mL}$ heated vegetable oil may typically equal a $\mathrm{PV}$ of $0.3 \mathrm{meq}$ and an alkenal content of $39.3 \mu \mathrm{mol}$. All calculations are based on the average values of PV and alkenals in Table 1.

There are only a few studies presenting the oxidative status of more than a few vegetable oils (24-26). However, there are several studies presenting effects on the stability of vegetable oils due to different kinds of heat processing $(17,36,37)$. In general, these studies show that oxidation 

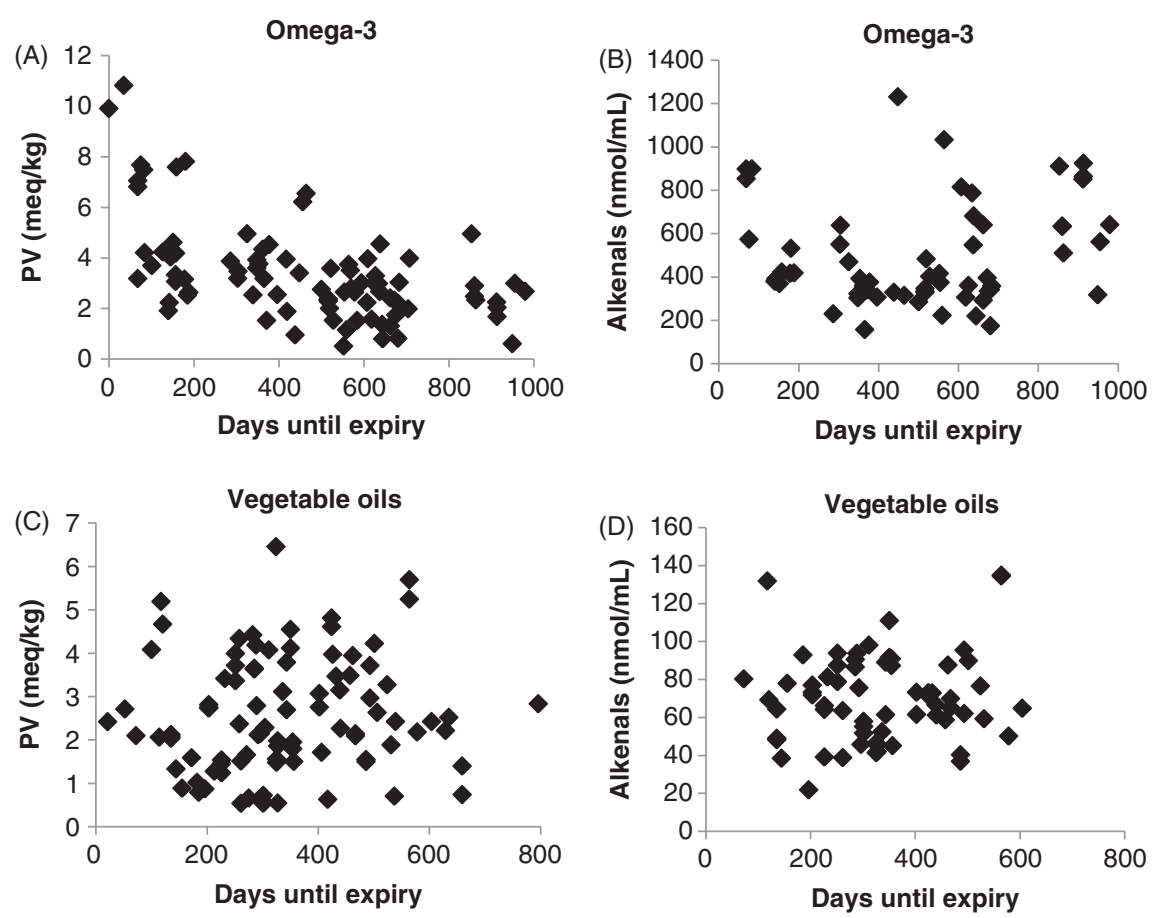

Fig. 2. $A-D$ Peroxide values (PV) (meq/kg) and alkenal concentration (nmol/mL) vs. number of days until expiry for marine omega-3 supplements and vegetable oils. All products were sealed until the day of analysis.

of oils increases when exposed to heat. A recent study by Silva et al. (38) shows that olive oils are more stable against heat $\left(180^{\circ} \mathrm{C}, \sim 60\right.$ minutes) than sunflower oil. This is consistent with results from the present study. However, they did not see the same increase for soybean oil, as compared to our study. The conditions in the present study were chosen to resemble a common food preparation practice with regard to temperature and the relatively short heating time compared to most other studies. It was not in the scope of this study to evaluate how different foods influence oxidation of oils during food processing. However, various types of food may affect the degree of lipid oxidation and degradation differently due to the variable content of transition metals (e.g. $\mathrm{Fe}, \mathrm{Cu}$ ), water etc. (39). Silva et al. (38) reported a protective effect from potatoes and meat on the lipid oxidation of fried oils, while Choe et al. (40) present results showing both increase and decrease in oxidation of fried oils by the presence of different foods.

In conclusion, it is well established that a diet rich in PUFA and low in SF is health beneficial (1). However, this screening of oxidative status of commercially available omega-3 supplements and vegetable oils shows that the content of oxidation products varies. The content of hydroperoxides and alkenals in marine omega-3 supplements are far higher than in fresh vegetable oils. Heating of vegetable oils increases the levels of alkenals considerably. However, due to a larger intake of vegetable oils in the diet compared to fish oil supplements, the former is the largest source of primary as well as secondary oxidation products in the diet. Despite the biological toxicity of several secondary lipid oxidation products, such as 4-hydroxy-2-alkenals, an upper limit corresponding to a safe dose of these compounds has not been established. Today little is known about what dose that may constitute a health hazard for humans. The potentially harmful doses and effects of oxidized oils should be studied in more details.

\section{Disclaimer}

Information about trade names or commercial products does not imply endorsement by the authors, and are reported as descriptive information for research applications only.

\section{Conflict of interest and funding}

$\mathrm{RB}$ has an interest in AS Vitas. BLH has no conflict of interest. This work was funded by the Norwegian Cancer Society, the Research Council of Norway and the Throne Holst foundation.

\section{References}

1. FAO/WHO. Fats and fatty acids in human nutrition. Proceedings of the Joint FAO/WHO Expert Consultation. November 10-14, 2008. Geneva, Switzerland. Ann Nutr Metab 2009; 55 (1-3): 5-300. Summary and recommendations: http://www.who.int/ nutrition/topics/FFA_summary_rec_conclusion.pdf

2. Adkins Y, Kelley DS. Mechanisms underlying the cardioprotective effects of omega-3 polyunsaturated fatty acids. J Nutr Biochem 2010; 21: 781-92. 
3. Marik PE, Varon J. Omega-3 dietary supplements and the risk of cardiovascular events: a systematic review. Clin Cardiol 2009; 32: $365-72$.

4. Turner R, McLean CH, Silvers KM. Are the health benefits of fish oils limited by products of oxidation? Nutr Res Rev 2006; 19: 53-62.

5. Kanner J. Dietary advanced lipid oxidation endproducts are risk factors to human health. Mol Nutr Food Res 2007; 51: 1094 101.

6. Nawar WW. Chemical-changes in lipids produced by thermalprocessing. J Chem Educ 1984; 61: 299-302.

7. Quiles JL, Huertas JR, Battino M, Ramirez-Tortosa MC, Cassinello M, Mataix J, et al. The intake of fried virgin olive or sunflower oils differentially induces oxidative stress in rat liver microsomes. Br J Nutr 2002; 88: 57-65.

8. Grootveld M, Atherton MD, Sheerin AN, Hawkes J, Blake DR, Richens TE, et al. In vivo absorption, metabolism, and urinary excretion of $\alpha, \beta$-unsaturated aldehydes in experimental animals - Relevance to the development of cardiovascular diseases by the dietary ingestion of thermally stressed polyunsaturate-rich culinary oils. J Clin Invest 1998; 101: 1210-8.

9. Zarate J, Goicoechea E, Pascual J, Echevarria E, Guillen MD. A study of the toxic effect of oxidized sunflower oil containing 4hydroperoxy-2-nonenal and 4-hydroxy-2-nonenal on cortical TrkA receptor expression in rats. Nutr Neurosci 2009; 12: 249-59.

10. Berry JD, Prineas RJ, Van HL, Passman R, Larson J, Goldberger J, et al. Dietary fish intake and incident atrial fibrillation (from the Women's Health Initiative). Am J Cardiol 2010; 105: 844-8.

11. Damsgaard CT, Frokiaer H, Andersen AD, Lauritzen L. Fish oil in combination with high or low intakes of linoleic acid lowers plasma triacylglycerols but does not affect other cardiovascular risk markers in healthy men. J Nutr 2008; 138: 10616.

12. Choe E, Min DB. Mechanisms and factors for edible oil oxidation. Comp Rev Food Sci Food Safety 2006; 5: 169-86.

13. Pillon NJ, Soulere L, Vella RE, Croze M, Care BR, Soula HA, et al. Quantitative structure-activity relationship for 4-hydroxy2-alkenal induced cytotoxicity in L6 muscle cells. Chem Biol Interact 2010; 188: 171-80.

14. Surh J, Kwon H. Estimation of daily exposure to 4-hydroxy-2alkenals in Korean foods containing n-3 and n-6 polyunsaturated fatty acids. Food Addit Contam 2005; 22: 701-8.

15. Dhaouadi A, Monser L, Sadok S, Adhoum N. Flow-injection methylene blue-based spectrophotometric method for the determination of peroxide values in edible oils. Anal Chim Acta 2006; 576: $270-4$.

16. Dobarganes MC, Velasco J. Analysis of lipid hydroperoxides. Eur J Lipid Sci Technol 2002; 104: 420-8.

17. Fullana A, Carbonell-Barrachina AA, Sidhu S. Comparison of volatile aldehydes present in the cooking fumes of extra virgin olive, olive, and canola oils. J Agric Food Chem 2004; 52: $5207-$ 14.

18. Guillen MD, Cabo N. Fourier transform infrared spectra data versus peroxide and anisidine values to determine oxidative stability of edible oils. Food Chem 2002; 77: 503-10.

19. Osawa CC, Goncalves LAG, Ragazzi S. Determination of hydroperoxides in oils and fats using kits. J Sci Food Agric 2007; 87: 1659-66.
20. Yildiz G, Wehling RL, Cuppett SL. Comparison of four analytical methods for the determination of peroxide value in oxidized soybean oils. J Am Oil Chem Soc 2003; 80: 103-7.

21. Claxson AW, Hawkes GE, Richardson DP, Naughton DP, Haywood RM, Chander CL, et al. Generation of lipid peroxidation products in culinary oils and fats during episodes of thermal stressing: a high field $1 \mathrm{H}$ NMR study. FEBS Lett 1994; 355: 81-90.

22. Osawa CC, Goncalves LAG, Ragazzi S. The use of fast methodologies (kits) in evaluating deep-frying oils. J Am Oil Chem Soc 2007; 84: 893-7.

23. Foo SY, Cuppett S, Schlegel V. Evaluation of SafTest (TM) methods for monitoring frying oil quality. J Am Oil Chem Soc 2006; 83: 15-20.

24. Galvano F, La FL, Graziani G, Ferracane R, Masella R, Di GC, et al. Phenolic compounds and antioxidant activity of Italian extra virgin olive oil Monti Iblei. J Med Food 2007; 10: $650-6$.

25. Gan HL, Man YBC, Tan CP, NorAini I, Nazimah SAH. Characterisation of vegetable oils by surface acoustic wave sensing electronic nose. Food Chem 2005; 89: 507-18.

26. Tan CP, Che Man YB, Selamat J, Yusoff MSA. Comparative studies of oxidative stability of edible oils by differential scanning calorimetry and oxidative stability index methods. Food Chem 2002; 76: 385-9.

27. Kolanowski W. Omega-3 LC PUFA Contents and Oxidative Stability of Encapsulated Fish Oil Dietary Supplements. Int J Food Prop 2010; 13: 498-511.

28. Ramírez-Tortosa C, López-Pedrosa JM, Suarez A, Ros E, Mataix J, Gil A. Olive oil- and fish oil-enriched diets modify plasma lipids and susceptibility of LDL to oxidative modification in free-living male patients with peripheral vascular disease: the Spanish Nutrition Study. Br J Nutr 1999; 82: 31-9.

29. Perona JS, Montero E, Sanchez-Dominguez JM, Canizares J, Garcia M, Ruiz-Gutierrez V. Evaluation of the effect of dietary virgin olive oil on blood pressure and lipid composition of serum and low-density lipoprotein in elderly type 2 diabetic subjects. J Agric Food Chem 2009; 57: 11427-33.

30. Estruch R, Martinez-Gonzalez MA, Corella D, Salas-Salvado J, Ruiz-Gutierrez V, Covas MI, et al. Effects of a Mediterraneanstyle diet on cardiovascular risk factors: a randomized trial. Ann Intern Med 2006; 145: 1-11.

31. Alonso A, Ruiz-Gutierrez V, Martinez-Gonzalez MA. Monounsaturated fatty acids, olive oil and blood pressure: epidemiological, clinical and experimental evidence. Public Health Nutr 2006; 9: 251-7.

32. Gunstone F (ed.). Fatty acid and lipid chemistry, 1st edition. Glasgow, UK: Blackie Academic \& Professional; 1996. p. 103-4.

33. Boran G, Karacam H, Boran M. Changes in the quality of fish oils due to storage temperature and time. Food Chem 2006; 98: 693-8.

34. Esterbauer H, Schaur RJ, Zollner H. Chemistry and biochemistry of 4-hydroxynonenal, malonaldehyde and related aldehydes. Free Radic Biol Med 1991; 11: 81-128.

35. Norwegian Food-Based Dietary Guidelines for public health promotion and prevention of chronic diseases - Methodology and scientific evidence. IS-1881. National Council on Nutrition, Oslo 2011

36. Tan CP, Man YBC, Jinap S, Yusoff MSA. Effects of microwave heating on changes in chemical and thermal properties of vegetable oils. J Am Oil Chem Soc 2001; 78: 1227-32. 
37. Houhoula DP, Oreopoulou V, Tzia C. A kinetic study of oil deterioration during frying and a comparison with heating. $\mathrm{J}$ Am Oil Chem Soc 2002; 79: 133-7.

38. Silva L, Pinto J, Carrola J, Paiva-Martins F. Oxidative stability of olive oil after food processing and comparison with other vegetable oils. Food Chem 2010; 121: 1177-87.

39. Sanchez-Muniz FJ. Oils and fats: changes due to culinary and industrial processes. Int J Vitam Nutr Res 2006; 76: 230-7.

40. Choe E, Min DB. Chemistry of deep-fat frying oils. J Food Sci 2007; 72: R77-86.
*Rune Blomhoff

Department of Nutrition

Institute of Basic Medical Sciences

University of Oslo

P.O. Box 1046 Blindern

0316 Oslo

Norway

Tel: +4722851395

Fax: +4722851398

Email: rune.blomhoff@medisin.uio.no 
Table S1. A detailed description of the encapsulated marine fish oil supplements examined in the present study

\begin{tabular}{|c|c|c|c|c|c|c|c|c|}
\hline Product, trade name & $\begin{array}{l}\text { Company: manufacturer } \\
\text { or distributor }\end{array}$ & Product type & $\begin{array}{l}\text { mg oil pr } \\
\text { capsule }\end{array}$ & $\begin{array}{l}\text { Total mg ome- } \\
\text { ga-3 pr capsule }\end{array}$ & $\begin{array}{l}\text { mg DHA pr } \\
\text { capsule }\end{array}$ & $\begin{array}{l}\text { mg EPA } \\
\text { pr capsule }\end{array}$ & $\begin{array}{l}\text { Recommended daily } \\
\text { dose, number of capsules }\end{array}$ & Type of antioxidant \\
\hline $\begin{array}{l}\text { Daily Wellness Biomega fish oil, highly } \\
\text { concentrated, } 60 \% \text { Omega-3 } 1000 \mathrm{mg}\end{array}$ & Daily Wellness, USA & $\begin{array}{l}\text { Unspecified fish oil } \\
\text { from deep-sea fish }\end{array}$ & 1000 & 600 & 200 & 300 & I & $\begin{array}{l}\text { Natural mix of } \\
\text { tocopherols }\end{array}$ \\
\hline $\begin{array}{l}\text { Daily Wellness Seal oil Omega-3, DPA, } \\
\text { EPA, DHA } 500 \mathrm{mg}\end{array}$ & Daily Wellness, USA & Seal oil & 500 & 102.5 & 41.2 & 31.3 & 6 & $d-\alpha$-Tocopherol \\
\hline Eskimo-3 with Pufanox & Cardinova, Sweden & Unspecified fish oil & n.s. ${ }^{a}$ & 170 & 55 & 85 & 3 & $\begin{array}{l}\text { Ascorbylpalmitat, } \\
\text { lecitin }\end{array}$ \\
\hline $\begin{array}{l}\text { Extra strong omega-3, with krill anti- } \\
\text { oxidant (from Biopharma) }\end{array}$ & Biopharma, Norway & $\begin{array}{l}\text { Unspecified fish oil and } \\
\text { krill oil }\end{array}$ & 500 & 285 & 177 & 90 & 2 & $d-\alpha$-Tocopherol \\
\hline Fri Flyt Omega-3 & $\begin{array}{l}\text { Vesterålens naturprodukter AS, } \\
\text { Norway }\end{array}$ & Unspecified fish oil & 530 & 350 & 110 & 165 & 2 & $d$ - $\alpha$-Tocopherol \\
\hline Krill-Omega & Pharmatec AS, Norway & $\begin{array}{l}\text { Unspecified fish oil } \\
\text { concentrate and krill } \\
\text { oil }\end{array}$ & n.s. ${ }^{a}$ & 285 & 177 & 90 & $2-4$ & $d-\alpha$-Tocopherol \\
\hline $\begin{array}{l}\text { Lofotkapselen, pure highly concen- } \\
\text { trated Omega-3 }\end{array}$ & OmegaVita, Norway & $\begin{array}{l}\text { Concentrated } \\
\text { anchovetas oil }\end{array}$ & 596 & 304 & 107.5 & 161 & 2 & $d-\alpha$-Tocopherol \\
\hline Möller's double & Axellus AS, Norway & $\begin{array}{l}\text { Unspecified fish oil } \\
\text { concentrate }\end{array}$ & n.s. ${ }^{a}$ & 350 & n.s. ${ }^{a, b}$ & n.s. ${ }^{a, b}$ & 2 & $\begin{array}{l}d-\alpha \text {-Tocopheryl acet- } \\
\text { ate }\end{array}$ \\
\hline $\begin{array}{l}\text { Möller's Omega- } 3 \text { highly concen- } \\
\text { trated, with peppermint taste }\end{array}$ & Axellus AS, Norway & Unspecified fish oil & n.s. ${ }^{a}$ & 500 & 200 & 250 & 2 & Tocopherols \\
\hline Natural Omega-3 (from Biopharma) & Biopharma AS, Norway & Unspecified fish oil & n.s. ${ }^{a}$ & 500 & 60 & 90 & $2-6$ & $d-\alpha$-Tocopherol \\
\hline Norwegian Fish oil, Salmon oil & Norwegian Fish oil AS, Norway & Salmon oil & 500 & n.s. ${ }^{a}$ & 45 & 30 & 2 & $\begin{array}{l}\text { Tocopherol, } \\
\text { rosemery extract, } \\
\text { ascorbylpalmitate }\end{array}$ \\
\hline Nycoplus Omega-3, 1000 mg & Nycomed Pharma, Norway & $\begin{array}{l}\text { Unspecified } \\
\text { concentrated fish oil }\end{array}$ & 1000 & n.s. ${ }^{a}$ & $220^{c}$ & $321.7^{c}$ & $\mathrm{I}-2$ & Tocopherols \\
\hline Nycoplus Seal oil, 1000 mg & Nycomed Pharma, Norway & Seal oil & 1000 & 200 & 80 & 60 & $2-3$ & $d-\alpha$-Tocopherol \\
\hline Oil4Life Cardio & $\begin{array}{l}\text { Produced in Norway for Itogha } \\
\text { AS }\end{array}$ & $\begin{array}{l}\text { Unspecified fish oil and } \\
\text { olive oil }\end{array}$ & & & & & & \\
\hline OmegaPro & VitaeLab AS, Norway & Unspecified fish oil & n.s. ${ }^{a}$ & 330 & 120 & 166.5 & 2 & $\begin{array}{l}\text { Extract rich in } \\
\text { tocopherols }\end{array}$ \\
\hline $\begin{array}{l}\text { Pikasol Hele deg, highly concentrated } \\
\text { Omega-3, } 880 \mathrm{mg}\end{array}$ & MöllerCollett AS, Norway & Unspecified fish oil & 880 & 530 & 185 & 265 & $2-5$ & Tocopherols \\
\hline PreviShop Omega-3 Forte, highly & PreviShop, marketed by Validus & Unspecified fish oil & 1000 & 600 & 220 & 330 & 2 & $d-\alpha$-Tocopherol \\
\hline
\end{tabular}


Table S1 (Continued)

\begin{tabular}{|c|c|c|c|c|c|c|c|c|}
\hline Product, trade name & $\begin{array}{l}\text { Company: manufacturer } \\
\text { or distributor }\end{array}$ & Product type & $\begin{array}{l}\mathrm{mg} \text { oil pr } \\
\text { capsule }\end{array}$ & $\begin{array}{l}\text { Total mg ome- } \\
\text { ga-3 pr capsule }\end{array}$ & $\begin{array}{l}\text { mg DHA pr } \\
\text { capsule }\end{array}$ & $\begin{array}{l}\text { mg EPA } \\
\text { pr capsule }\end{array}$ & $\begin{array}{c}\text { Recommended daily } \\
\text { dose, number of capsules }\end{array}$ & Type of antioxidant \\
\hline Ruis Omega-3 Seal oil, capsules ${ }^{d}$ & $\begin{array}{l}\text { Produced for Naturkost S. Rui } \\
\text { as, Norway and Medica Nord, } \\
\text { Norway }^{d}\end{array}$ & Seal oil & 750 & 140 & $65^{d}$ & $52.6^{d}$ & 46 & $d-\alpha$-Tocopherol \\
\hline $\begin{array}{l}\text { Ruis Omega-3 Seal oil, highly } \\
\text { concentrated }\end{array}$ & $\begin{array}{l}\text { Produced for Medica Nord, } \\
\text { Norway }\end{array}$ & Seal oil & 1000 & 360 & 150 & 80 & $\mathrm{I}-2$ & $\begin{array}{l}\text { Extract rich in toco- } \\
\text { pherols }\end{array}$ \\
\hline Seal oil (from Biopharma) & Biopharma, Norway & Seal oil & 500 & 105 & 34 & 42 & $2-3$ & $d-\alpha$-Tocopherol \\
\hline Suncap Omega-3 & $\begin{array}{l}\text { Produced by Lysi, Iceland for } \\
\text { SunCap, Norway }\end{array}$ & Unspecified fish oil & 550 & 165 & 66 & 99 & 2 & Vitamin E \\
\hline $\begin{array}{l}\text { Triomega Original, highly } \\
\text { concentrated }\end{array}$ & Midelfart Sonesson, Norway & Unspecified fish oil & 500 & 310 & 108.5 & 155 & $2-3$ & Tocopherols \\
\hline Triomega, Omega-3+Q10, heart & Midelfart Sonesson, Norway & $\begin{array}{l}\text { Concentrated } \\
\text { unspecified fish oil }\end{array}$ & n.s. ${ }^{a}$ & 410 & 138.5 & 198.5 & 2 & Coenzyme QI0 \\
\hline $\begin{array}{l}\text { Triple Omega-3, extra strong (from } \\
\text { Biopharma) }\end{array}$ & Biopharma, Norway & Unspecified fish oil & 500 & 325 & 110 & 165 & 2 & $d-\alpha$-Tocopherol \\
\hline
\end{tabular}

${ }^{a}$ Not specified on the label.

${ }^{b} \mathrm{EPA}+\mathrm{DHA}=250 \mathrm{mg} / \mathrm{capsule}$.

' One box claimed a different content than the two others. This value is an average of the three boxes. Box I and 2: DHA $=225 \mathrm{mg} / \mathrm{capsule}, \mathrm{EPA}=325 \mathrm{mg} / \mathrm{capsule}, \mathrm{Box} 3$ : $\mathrm{DHA}=210 \mathrm{mg} / \mathrm{capsule}, \mathrm{EPA}=315$ $\mathrm{mg} / \mathrm{capsule.}$

${ }^{\text {T}}$ This product was produced for two different distributors. Two of the boxes were produced for Medica Nord AS, Norway and the other two for Naturkost $\mathrm{S}$. Rui as, Norway. The value presented in the table is an average of four boxes. The two boxes with Medica Nord logo contain: total omega- $3=122.5 \mathrm{mg} /$ capsule, DHA = $48 \mathrm{mg} / \mathrm{capsule,} \mathrm{EPA}=41.3 \mathrm{mg} / \mathrm{capsule}$ The two boxes with Naturkost logo contain: total omega-3 = 157,5 mg/capsule, DHA =82 mg/capsule, EPA =64 mg/capsule. However, these differences are most likely due to different batches. Also the liquid version of Ruis seal oil that were tested were produced for the same two distributors. However, even though there were variations in fatty acid composition between the boxes, these differences were seen independently of distributor. 
Table S2. A detailed description of the liquid marine fish oil supplements examined in the present study

\begin{tabular}{|c|c|c|c|c|c|c|c|}
\hline Product, Trade name & $\begin{array}{l}\text { Company: manufacturer } \\
\text { or distributor }\end{array}$ & Product type & $\begin{array}{l}\text { Total mg omega- } \\
3 \mathrm{pr} \mathrm{mL} \text { oil }\end{array}$ & $\begin{array}{l}\mathrm{mg} \text { DHA pr } \\
\mathrm{mL} \text { oil }\end{array}$ & $\begin{array}{l}\mathrm{mg} \text { EPA pr } \\
\mathrm{mL} \text { oil }\end{array}$ & $\begin{array}{l}\text { Recommended daily dose } \\
\text { for adults, } \mathrm{mL}\end{array}$ & Type of antioxidant \\
\hline Eskimo-3 kids, with Tutti- Frutti taste & Cardinova $A B$, Sweden & $\begin{array}{l}\text { Unspecified fish oil and } \\
\text { rape(seed) oil }\end{array}$ & 240 & 56 & 82 & $5^{\mathrm{a}}$ & Natural tocopherols \\
\hline Lofot cod liver oil & Lofotprodukt AS, Norway & Cod liver oil & 220 & 100 & 80 & 5 & $d-\alpha$-tocopherol \\
\hline Möller's cod liver oil, natural & Axellus AS, Norway & Cod liver oil & 240 & 120 & 80 & 5 & $\begin{array}{l}\mathrm{dl}-\alpha \text {-Tocopheryl acetate, } \\
\text { natural tocopherols }\end{array}$ \\
\hline Möller's Extra Omega-3 cod liver oil & Axellus AS, Norway & $\begin{array}{l}\text { Cod liver oil and } \\
\text { unspecified fish oil }\end{array}$ & 340 & 180 & 120 & 5 & $\begin{array}{l}\mathrm{dl}-\alpha \text {-Tocopheryl acetate, } \\
\text { natural tocopherols }\end{array}$ \\
\hline Nycoplus Apotekets cod liver oil, lemon taste & $\begin{array}{l}\text { Nycomed Pharma AS, } \\
\text { Norway }\end{array}$ & Cod liver oil & 220 & 100 & 80 & 5 & $d-\alpha$-Tocopherol \\
\hline Oil4Life Cardio & $\begin{array}{l}\text { Produced in Norway for } \\
\text { Itogha AS }\end{array}$ & $\begin{array}{l}\text { Cod liver oil and } \\
\text { cold-pressed olive oil }\end{array}$ & 210 & 50 & 100 & 15 & $\begin{array}{c}\text { Natural antioxidants from } \\
\text { olive oil }\end{array}$ \\
\hline OliVita oil, Seal oil and Olive oil & OliVita, Norway & $\begin{array}{l}\text { Seal oil, extra virgin } \\
\text { olive } \\
\text { oil }\end{array}$ & 120 & 48 & 35 & 15 & \\
\hline Pure Arctic Omega-3 & Biopharma, Norway & Unspecified fish oil & 360 & 120 & 180 & 5 & $d-\alpha$-Tocopherol \\
\hline $\begin{array}{l}\text { Ruis OliMar Pluss, Omega-3 Seal oil with olive } \\
\text { leaf extract, grape seed oil and vitamin K2 }\end{array}$ & Naturkost S. Rui, Norway & $\begin{array}{l}\text { Seal oil, grapeseed oil } \\
\text { (olive leaf extract, nat- } \\
\text { to) }\end{array}$ & 140 & 63.2 & 49.6 & 15 & \\
\hline Ruis Omega-3 Seal oil, liquid ${ }^{b}$ & $\begin{array}{l}\text { Produced for Naturkost S. } \\
\text { Rui, Norway, and Medica } \\
\text { Nord, Norway }{ }^{b}\end{array}$ & Seal oil & $169.4^{b}$ & $72^{b}$ & $59^{b}$ & 10 & $d-\alpha$-Tocopherol \\
\hline
\end{tabular}

${ }^{a}$ Recommended for kids.

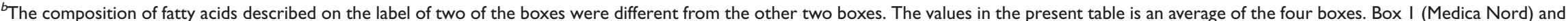
box 2 (Naturkost): Total omega-3=186.76 mg/mL, DHA =84 mg/mL, EPA =67 mg/mL. Box 3 and 4 (both MedicaNord): Total omega- $3=152 \mathrm{mg} / \mathrm{mL}, \mathrm{DHA}=60 \mathrm{mg} / \mathrm{mL}$, EPA $=5 \mathrm{Img} / \mathrm{mL}$. 